To be presented at the International Symposium on Sulfur in the Atmosphere,

Dubrovnik, Yugoslavia,

September $7-14,1977$

\title{
LARGE-SCALE MEASUREMENT OF \\ AIRBORNE PARTICULATE SULFUR
}

B. W. Loo, W. R. French, R. C. Gatti,

F. S. Goulding, J. M. Jaklevic, J. Llacer, and

A. C. Thompson

August 1977

Prepared for the U. S. Energy Research and

Development Administration under Contract W-7405-ENG-48

\section{For Reference}

Not to be taken from this room

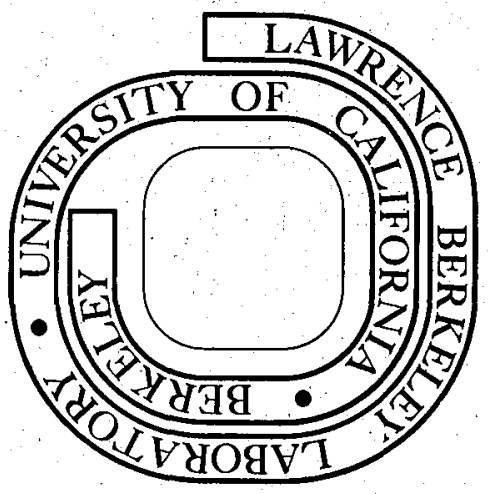

RE $C_{0} E D$

LA:NOCNCE

BREMOY LASTBRORY

OCT 171977

LIBFARY AND DOCUMEMTS SECTION 
This report was prepared as an account of work sponsored by the United States Government. Neither the United States nor the United States Energy Research and Development Administration, nor any of their employees, nor any of their contractors, subcontractors, or their employees, makes any warranty, express or implied, or assumes any legal liability or responsibility for the accuracy, completeness or usefulness of any information, apparatus, product or process disclosed, or represents that its use would not infringe privately owned rights. 


\section{LARGE-SCALE MEASUREMENT OF AIRBORNE PARTICULATE SULFUR*}

B. W. Loo, W. R. French, R. C. Gatti, F. S. Goulding

J. M. Jaklevic, J. LTacer and A. C. Thompson

$$
\begin{gathered}
\text { Lawrence Berkeley Laboratory } \\
\text { University of California } \\
\text { Berkeley, California } 94720 \text { U.S.A. }
\end{gathered}
$$

*This work was supported by the Environmental Protection Agency under Interagency Agreement with the United States Energy Research and Development Administration. 


\section{ABSTRACT}

We describe an aerosol sampling and analysis system which represents an integral approach to large-scale monitoring of airborne particulate matter. During our two-year participation in the St. Louis, Missouri, Regional Air Pollution Study (RAPS), 34,000 size-fractionated samples were collected by automated dichotomous samplers characterized by a particle size cutpoint of $2.4 \mu \mathrm{m}$. The total mass of the particulate matter was measured by betamparticle attenuation and the elemental composition, including sulfur, was determined by photon-excited $x$-ray fluorescence. The long-term performance of the system will be reported.

Potential systematic effects related to the sampling and analysis of sulfur particles are treated here in detail. Both the accuracy and precision of sulfur measurement are estimated to be $2 \%$. While the $x$-ray attenuation correction required is typically only a few percent, a larger correction is required for a small fraction of the samples due to the migration of the sulfur into the filter. This correction is derived from the ratio of sulfur determinations made on the front and back surfaces of the membrane filter. Laboratory and field experiments have shown insignificant gaseous $\mathrm{SO}_{2}$ conversion on the type of filters employed in the study.

Preliminary data on the composition and the temporal and spatial distribution of the St. Louis aerosol are presented. About $90 \%$ of the sulfur was found in the fine-particle fraction. Sulfur variations were significantly slower than those of the trace elements. Sulfates usually constitute about $35 \%$ of the total fine-particle mass, but may rise to $41 \%$ during an "episode."

The long-term ( 4 month average) sulfur data indicate that the background air masses arriving at St. Louis from the west and north were about 30\% lower in particulate sulfur than those from the east and south. Also, an urban station may experience local increases in sulfur level up to a factor of two greater than the general background. Shortterm ( 6 hour average) data indicate that the effects of stationary $\mathrm{SO}_{2}$ sources extend for long distances, (at least $40 \mathrm{~km}$ ) and are highly directional in character. 


\section{INTRODUCTION}

In the course of the St. Louis, Missouri, Regional Air Pollution Study (RAPS), we have collected 34,000 size-fractionated aerosol samples at ten of the regional monitoring sites. Total particulate mass and elemental compositions have been measured separately for the coarse- and fine-particle fractions, which have aerodynamic diameters above and below $2.4 \mu \mathrm{m}$, respectively. The results provide an unprecedented opportunity to study spatial and temporal variations of aerosol particles in a large metropolitan area, particularly those of sulfur-containing particles which are a major and growing component of the aerosol mass.

Fine airborne particulate sulfur is present in the air almost entirely in the respirable particle-size range and is therefore a threat to human heaith. Furthermore, it is a secondary aerosol from its gaseous $\mathrm{SO}_{2}$ precursor; thus, its space and time behavior may hold much of the secret to understanding the process of atmospheric transformation, transport, and depletion of aerosols. In view of these factors, which make sulfur so important, emphasis in this paper will be on the problems associated with sulfur analysis. Preliminary data, illustrating the temporal and spatial distribution of sulfur and aerosol mass, are presented. The regional variation of particulate sulfur as related to wind direction and major stationary $\mathrm{SO}_{2}$ emission sources is also examined.

\section{METHOD}

When laboratory techniques are used in the field, reliability becomes a crucial problem. The large scope of the RAPS program requires a systematic approach, with rigorous quality assurance measures applied during the complete cycle of sample collection, sample measurement, and data processing. We have chosen methods that are nondestructive, and which require no sample preparation and are easily automated for a minimum amount of operator handling. 
The urban aerosol size distribution is bimodal, with the fine (respirable) combustion-generated particles being distinct from the coarse aerosol generated by mechanical and natural processes. (Whitby, 1972, 1973) In order to sample these fractions separately, we developed the automated dichotomous sampler, which uses the virtual impactor principle. (Loo, 1976) This sampler inertialiy separates particles according to their aerodynamic size--either above or below $2.4 \mu \mathrm{m}--$ and collects each fraction uniformly on a separate filter, with minimum particle loss and re-entrainment. An automated flow controller including fault sensors were built into the sampler so that precise flow conditions and the timing sequence were thoroughly checked and maintained.

The filters used $(1.2 \mu \mathrm{m}$ pore size cellutose ester such as Militipore Type RAWP) have a fairly low impurity content and high filtration efficiency. (Liu, 1977) The $37 \mathrm{~mm}$ diameter filter discs were mounted in $5 \mathrm{~cm}$ square plastic frames and loaded in standard photographic slide projector cartridges. The cartridges, which hold 36 slides in a linear array, were then automatically sequenced through both the sampling and the analysis equipment. Thus, the exact chronological order of the samples was easily maintained.

The mass deposited on the filter was measured with a beta gauge utilizing a $\mathrm{Pm}^{147}$ source and a large-area semiconductor detector. (Goulding, 1975) The mass difference on a typical $4.5 \mathrm{mg} / \mathrm{cm}^{2}$ filter before and after particle collection could be determined to a precision of $10 \mathrm{\mu g} / \mathrm{cm}^{2}$ by using a $30-\mathrm{sec}$ counting period and making corrections for relative humidity and other systematic effects. This corresponds to an error of $2 \mu \mathrm{g} / \mathrm{m}^{3}$ in the measured atmospheric aerosol concentration for a 12-hour sample.

Elemental compositions were measured using energy-dispersive $x$-ray fluorescence (XRF) analysis. Concentrations of 27 elements, ranging from $\mathrm{Al}$ to $\mathrm{Ba}$ and including $\mathrm{Hg}$ and $\mathrm{Pb}$, are routinely measured in a time of less than 5 minutes per sample. Extensive investigations and validation studies of XRF measurements have established the value of this method for the analysis of aerosol specimens. (Appel 1977, Camp 1975, Dzubay 1977) Since ambient aerosol sulfur is present overwhelmingty in 
the form of sulfates, the result of elemental sulfur measurement by XRF can be closely related to atmospheric sulfates. (Stevens, 1978) The XRF method is sensitive and specific and, when fully automated, is wellsuited for handling a large number of samples. The nondestructive nature of the method is important from the standpoint of data validation and assessment of long-term systematic effects. (Jaklevic, 1977)

Figure 1 is a block diagram of the entire sampling and analysis system. Mounted filters were labeled and beta-gauged for tare weights before they were dispatched to the RAPS sampling sites. The exposed filters were then returned to us for analytical measurements and subsequent data analysis.

\section{SYSTEM PERFORMANCE}

The success of the sampling program is illustrated by examining the reliability of the field operation. Of 34,000 samples collected in the RAPS network, $97.2 \%$ were validated, uninterrupted, synchronous samples. About $0.7 \%$ of the samples were rejected due to sampler malfunctions; $1.7 \%$ were rejected because of computer interference and ac power failures during the early months of operations; and $0.4 \%$ were excluded because of excessive loading of the filter-a problem which was largely avoided in the later phases of the study by reducing the sampling periods at the susceptible stations.

To illustrate the precision of the XRF technique, a typical St. Louis fine-aerosol sample was measured repeatedly. Table 1 lists the mean values and standard deviations of six periodic measurements over a two-month period. Results are given for all elements routinely measured. The minimum detectable limits (MDL) (Jaklevic, 1977A) (using a typical analysis time of 1.2 minutes for each of the three excitation energies employed for the analysis) are also listed for comparison. For major elements, such as sulfur and lead, where systematics dominate over counting statistics, measurements were reproducible to about $1 \%$.

To determine the fluctuations in aerosol concentration measurement caused by the samplers, three of the units were operated side by side 


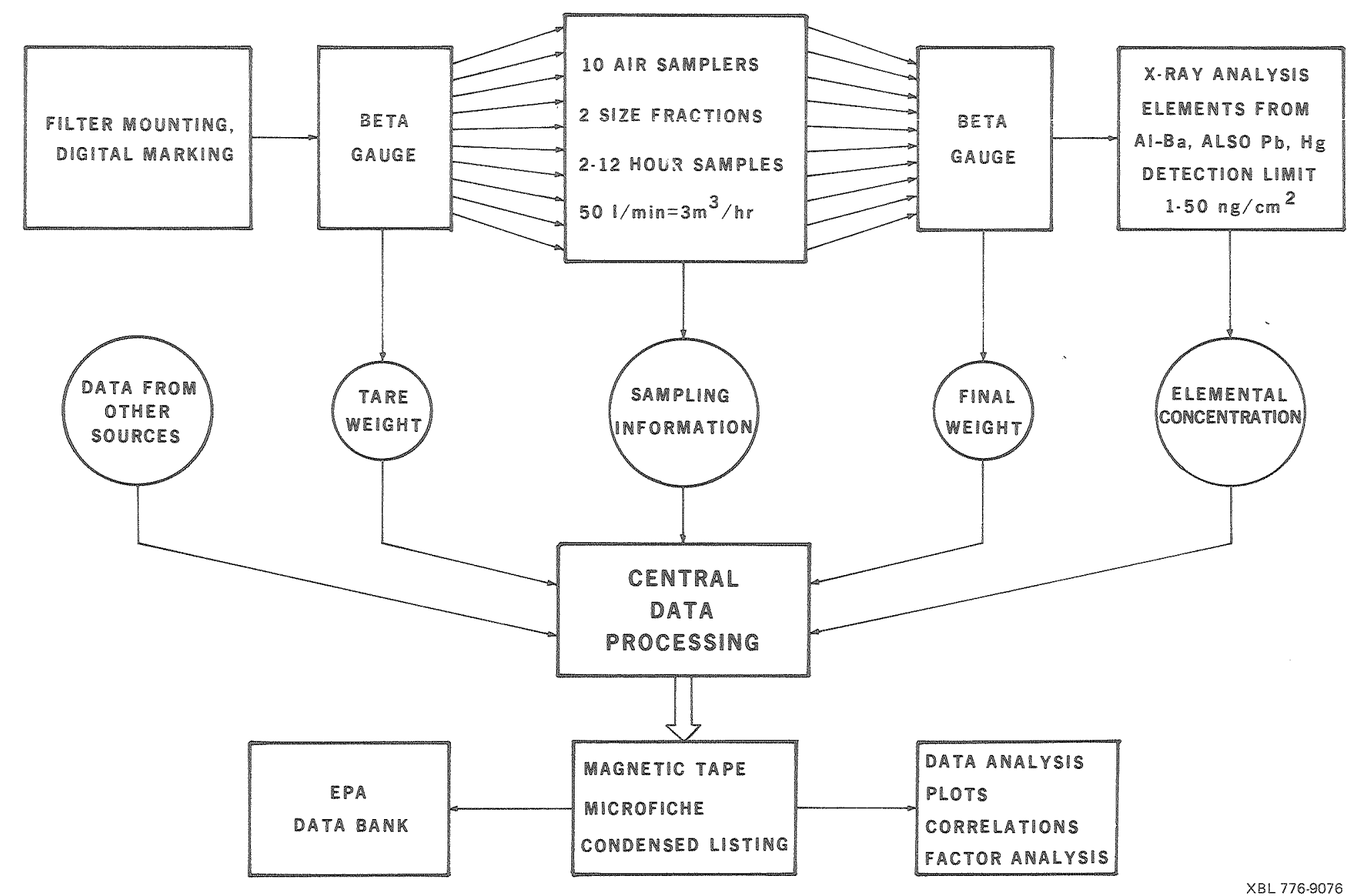

Fig. I Block diagram of sampling, measurement, and data analysis system 


\begin{tabular}{|c|c|c|c|}
\hline ELEMENT & $\begin{array}{l}\text { MEAN } \\
\text { CONCENTRATION } \\
\left(\mathrm{ng} / \mathrm{cm}^{2}\right)\end{array}$ & $\begin{array}{l}\text { STANDARD } \\
\text { DEVIATION } \\
\left(\mathrm{ng} / \mathrm{cm}^{2}\right)\end{array}$ & $\begin{array}{l}\text { MINIMUM } \\
\text { DETECT } \\
\text { LIMTT } \\
\left(\mathrm{ng} / \mathrm{cm}^{2}\right)\end{array}$ \\
\hline $\mathrm{Al}$ & 226 & 150 & 153 \\
\hline $\mathrm{Si}$ & 214 & 37 & 63 \\
\hline $\mathrm{P}$ & 44 & 41 & 40 \\
\hline S & 11675 & 121 & 34 \\
\hline $\mathrm{Cl}$ & 224 & 24 & 28 \\
\hline K & 222 & 8 & 12 \\
\hline $\mathrm{Ca}$ & 196 & 41 & 62 \\
\hline $\mathrm{Ti}$ & 26 & 19 & 31 \\
\hline V & 11. & 6 & 21 \\
\hline $\mathrm{Cr}$ & 10 & 6 & 16 \\
\hline $\operatorname{Mn}$ & 16 & 9 & 13 \\
\hline $\mathrm{Fe}$ & 337 & 9 & 11 \\
\hline $\mathrm{Ni}$ & 6 & 2 & 6 \\
\hline $\mathrm{Cu}$ & 91 & 21 & 7 \\
\hline $\mathrm{Zn}$ & 495 & 7 & 6 \\
\hline $\mathrm{Ga}$ & 0 & 0 & 4 \\
\hline As & 3 & 4 & 3 \\
\hline $\mathrm{Se}$ & 6 & 2 & 3 \\
\hline $\mathrm{B} r$ & 84 & 2 & 3 \\
\hline $\mathrm{Rb}$ & 1 & 1 & 3 \\
\hline $\mathrm{Sr}$ & 1 & 1 & 4 \\
\hline $\mathrm{Hg}$ & 0 & 0 & 7 \\
\hline $\mathrm{Pb}$ & 632 & 3 & 10 \\
\hline $\mathrm{Cd}$ & 24 & 4 & 4 \\
\hline $\mathrm{Sn}$ & 30 & 8 & 5 \\
\hline $\mathrm{Sb}$ & 2 & 2 & 5 \\
\hline $\mathrm{Ba}$ & 5 & 6 & 22 \\
\hline
\end{tabular}

XBL 776-9072

Table 1 Long-term performance of the pulsed XRF spectrometer. Results of repetitive analysis of a sample over a 2 month period. 
for three 12-hour sampling periods. These samplers came straight from the field with no special preparation. The mean concentration and the standard deviations calculated for the samples produced in this test are listed in Table 2 for the representative elements $\mathrm{S}, \mathrm{Pb}$, and $\mathrm{Fe}$ in each of the size fractions analyzed. For example, the standard deviations between the three samples of fine-particle sulfur and lead are less than $0.5 \%$ and $1.3 \%$, respectively, illustrating the uniformity and long-term stability of the samplers.

\section{SULFUR ANALYSIS}

The importance of the sulfur measurement requires that the limitations and systematic effects associated with both sampling and analysis be fully understood. Results of the XRF analysis must be examined in detail since the analyses of light elements, such as sulfur, are known to be susceptible to systematic bias arising from $x$-ray attenuation effects. We ciiscuss here four areas of possible systematic error.

\section{(A) Calibration}

As shown earlier, the precision or long-term reproducibility of the XRF spectrometer is better than $2 \%$. The absolute accuracy of the method is well established in cases where $x$-ray attenuation is not significant. Calibration is normally performed either directly with gravimetrically weighed thin-film standards or indirectly through bootstrap calibrations based on laboratory generated aerosols of known elemental ratios. (Giauque, 1977)

For light element calibrations, corrections must be made for $x$-ray attenuation. We have established the accuracy of our sulfur calibration by comparing two independent bootstrap procedures using a series of accurately measured thin-film Cu standards as the starting point.

Figure 2 is an illustration of the two paths by which we arrived at our sulfur calibration. The $\mathrm{CuSO}_{4} \cdot 5 \mathrm{H}_{2} \mathrm{O}$ and $\mathrm{K}_{2} \mathrm{SO}_{4}$ specimens used were in the form of $0.3 \mu \mathrm{m}$ particles (generated at the Particle Technology Laboratory, University of Minnesota) deposited on the surface of 0.1 um pore size 


\begin{tabular}{|c|c|c|c|c|}
\hline ELEMENT & $\begin{array}{l}\text { PART } \\
\text { SIZE } \\
\text { FRACT }\end{array}$ & $\begin{array}{l}12 \text { HR } \\
\text { SAMPL ING } \\
\text { PER IOD } \\
\text { NUMBER }\end{array}$ & $\begin{array}{l}\text { MEAN } \\
\text { CONCEN- } \\
\text { TRATION } \\
\left(\mathrm{ng} / \mathrm{m}^{3}\right)\end{array}$ & $\begin{array}{l}\text { STAND } \\
\text { DEVIA } \\
\left(\mathrm{ng} / \mathrm{m}^{3}\right)\end{array}$ \\
\hline \multirow{6}{*}{$S$} & \multirow{3}{*}{ F } & 1 & 771 & 3 \\
\hline & & 2 & 1145 & 6 \\
\hline & & 3 & 1738 & 9 \\
\hline & \multirow{3}{*}{ C } & 1 & 109 & 11 \\
\hline & & 2 & 231 & 5 \\
\hline & & 3 & 269 & 7 \\
\hline \multirow{6}{*}{$\mathrm{Pb}$} & \multirow{3}{*}{ F } & 1 & 632 & 6 \\
\hline & & 2 & 1716 & 22 \\
\hline & & 3 & 1114 & 15 \\
\hline & \multirow{3}{*}{ C } & 1 & 229 & 6 \\
\hline & & 2 & 501 & 11 \\
\hline & & 3 & 378 & 15 \\
\hline \multirow{6}{*}{$\mathrm{Fe}$} & \multirow{3}{*}{$\mathrm{F}$} & 1 & 67 & 4 \\
\hline & & 2 & 230 & 5 \\
\hline & & 3 & 186 & 4 \\
\hline & \multirow{3}{*}{ C } & 1 & 1015 & 42 \\
\hline & & 2 & 2113 & 113 \\
\hline & & 3 & 1737 & 79 \\
\hline
\end{tabular}

XBL 776-9071

Table 2 Mean and standard deviations in analysis of samples collected simultaneously by 3 samples for 3 sampling periods. 


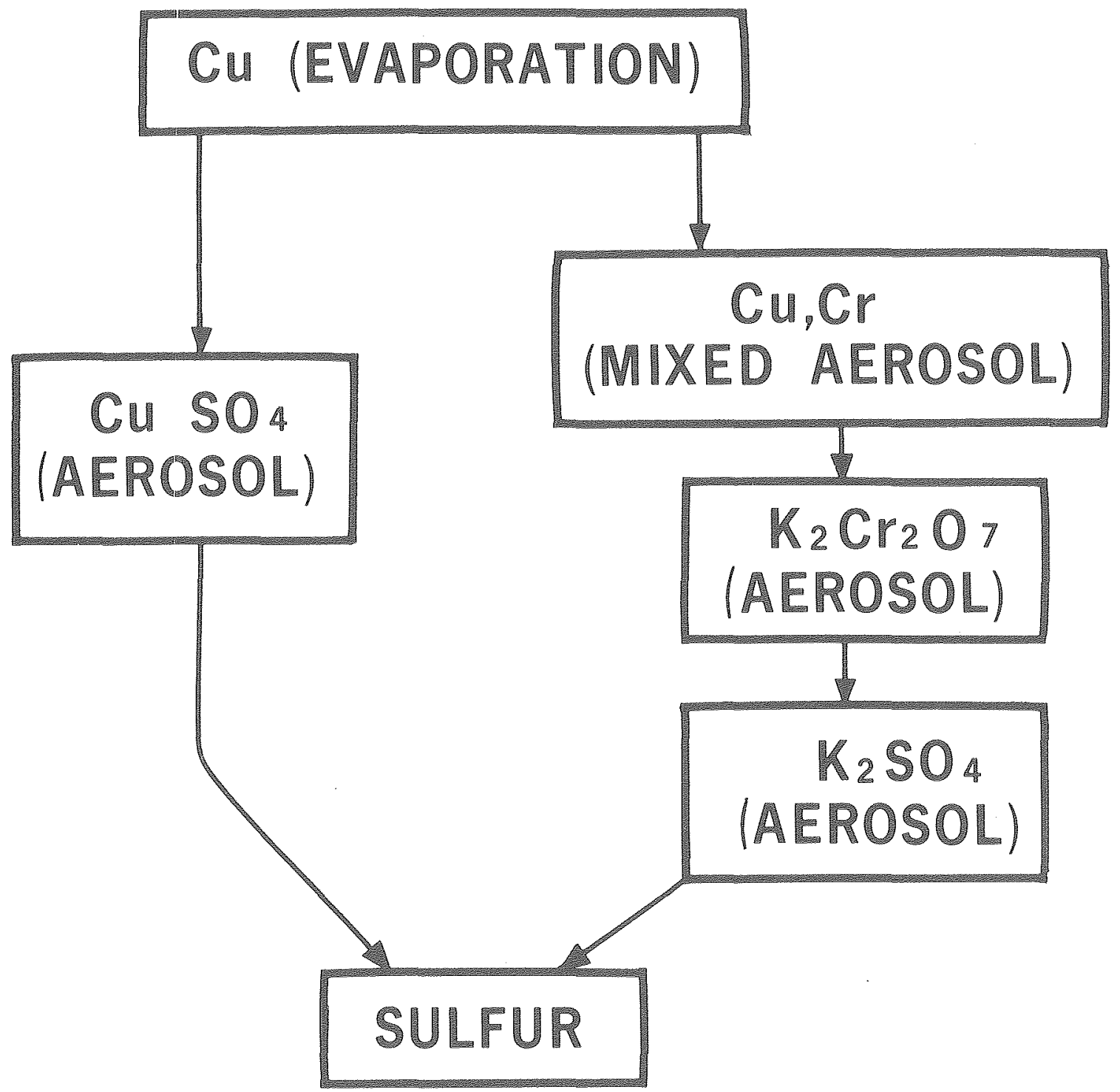

XBL 773-8013

Fig. 2 Two independent sulfur XRF bootstrap calibrations from a copper primary standard. 
Nuclepore filters. The results of the $[\mathrm{Cu} \rightarrow \mathrm{S}]$ and the $[\mathrm{Cu} \rightarrow \mathrm{Cr} \rightarrow \mathrm{K} \rightarrow \mathrm{S}]$ calibrations agreed to within $1 \%$.

(B) X-ray Attenuation Corrections

A detailed treatment of this subject has previously been given. (Loo, 1977) Here we review a few of the results.

(1) Since almost $90 \%$ of the sulfur-carrying particulates are in the fine-particle fraction, the use of the dichotomous sampler, which removes coarse-particle interference, greatly reduces the uncertainty due to absorption in individual particles ( $1 \%$ for $0.3 \mathrm{um}$ particles).

(2) The attenuation correction is typically about $5 \%$ for sulfur within a layer of fine ambient particles $200 \mu \mathrm{g} / \mathrm{cm}^{2}$ thick. This is the maximum loading of fine particles that the Millipore filter can accept without clogging.

(3) Direct measurements show that particles in the range of $0.05 \mu \mathrm{m}$ to $1 \mu \mathrm{m}$ diameter deposition the filter surface and do not penetrate significantly into the filter medium. Under these circumstances, the correction for sulfur $x$-ray attenuation by filter substrate is $3 \pm 3 \%$ 。

(C) Particle Migration

Our sulfur $x$-ray attenuation studies have shown that aerosol particles generated both in the field and in the laboratory collect almost entirely on the surface of the filter without significant penetration. However, systematic examination of a large collection of field samples reveals that, on occasion, aerosol material does migrate into a filter substrate. Figure 3 is an illustration of this problem: when all the sulfur particles reside on the front surface of a filter, the ratio of $S_{F}$ (the sulfur signal when the front side of the filter faces the detector) to $S_{B}$ (the sulfur signal when the back side of the filter faces the detector) should be in the range of 6 to 8 (depending on the thickness of the filter blank). 

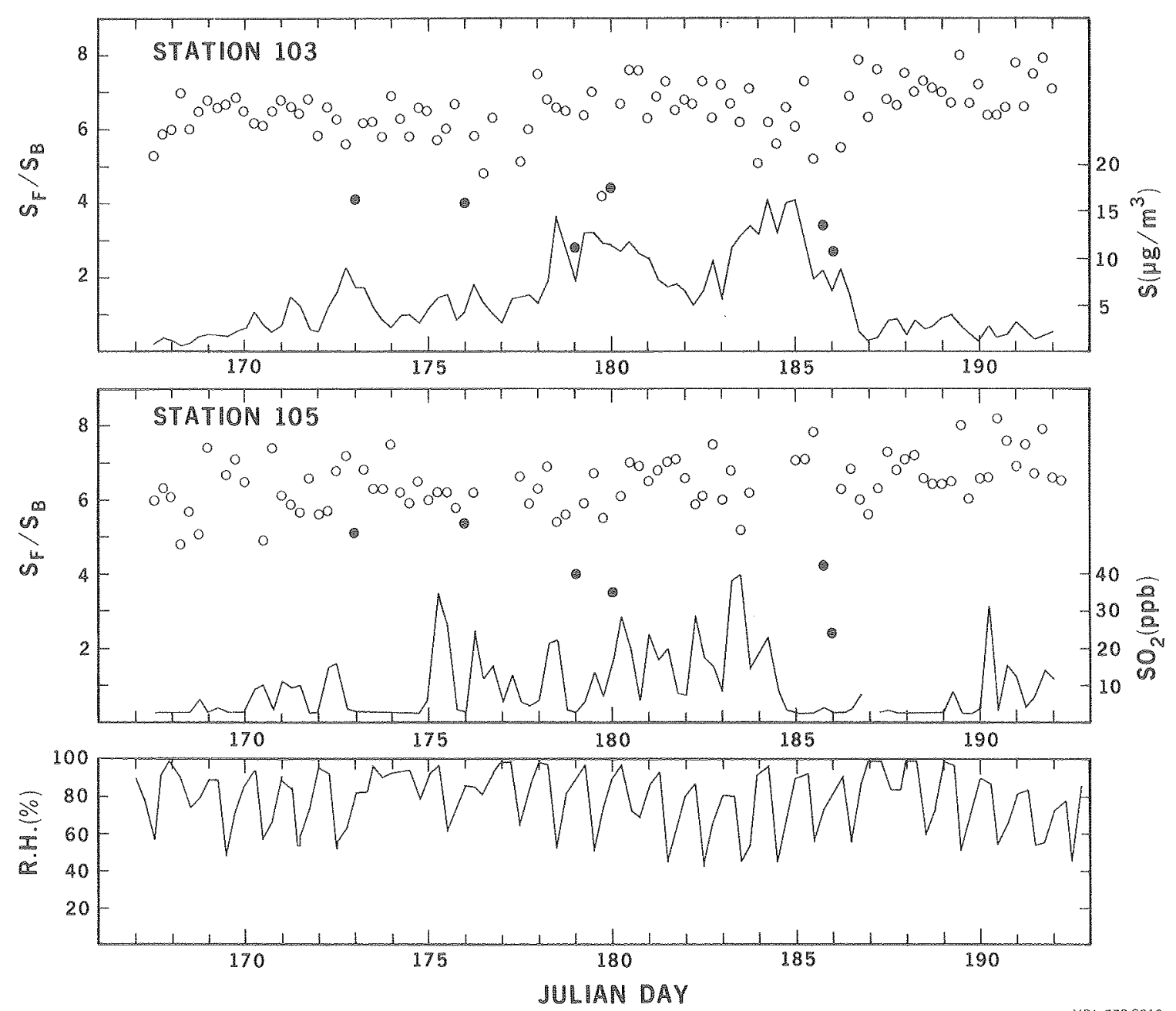

$X B L 7738010$

Fig. 3 Migration of aerosol material into the filter medium as evidenced by the ratios of the sulfur XRF yield for the front and back sides of the filters. 
Figure 3 shows the sulfur front-to-back ratio $S_{F} / S_{B}$ (open circles) for six-hour samples at RAPS stations 103 and 105 during the summer of 1975. A7so shown are the sulfur levels at stations 103 and $\mathrm{SO}_{2}$ levels at the station 105, together with the relative humidity variations. occasional low values of $S_{F} / S_{B}$ (solid dots) occurred, indicating a significant penetration of sulfur into the filter. The observation that these rare events occur simultaneously at two sampling locations suggests that they are weather-related. However, the coarse-particle filters obtained at the same time as these anomalous samples do not have low values of $S_{F} / S_{B}$, which eliminates precipitation as the cause. The poor correlation of low $\mathrm{S}_{F} / \mathrm{S}_{\mathrm{B}}$ with $\mathrm{SO}_{2}$ indicates that very little gaseous $\mathrm{SO}_{2}$ conversion can be occurring on the filter substrate.

Low $S_{F} / S_{B}$ does seem to correlate with a combination of high humidity and high sulfur loading. Subsequent laboratory tests have shown that typical fine aerosol samples loaded with $>10 \mu \mathrm{g} / \mathrm{cm}^{2}$ and exposed to $100 \%$ relative humidity exhibit a tendency for sulfur to migrate into the filter. Such migration is probably the result both of the hygroscopic nature of the particles and of the hydrophilic nature of the filter.

We have developed a simple correction technique for filter penetration based on measuring the front/back ratio of samples. This is now being applied to the St. Louis data.

The sulfur migration problem can be totally eliminated, if necessary, by using Teflon filters which are hydrophobic. Furthermore, the thinner Teflon filters $\left(1 \mu \mathrm{g} / \mathrm{cm}^{2}\right)$ also lowers the detection limits for the x-ray fluorescence analysis and improves the accuracy of mass determination by beta-gauging. However, Teflon filters become clogged with only a third of the mass loading that can be accepted by Millipore filters. In many applications this can be a major drawback.

\section{(D) Spurious Sulfate Formation}

It is well known that gaseous $\mathrm{SO}_{2}$ may be converted to form spurious sulfate on the filter when the filter material is alkaline, (Pierson, 1977) and that Millipore filters, being nonalkaline, are fairly immune to this process. Recently, however, it was reported that as much as $40 \%$ 
spurious sulfate (produced by $\mathrm{SO}_{2}$ conversion) was found an ambient aerosols collected on Millipore filters. (Lasko, 1977)

In collaboration with $R$. K. Stevens and $T$. G. Dzubay of the Environmental Protection Agency (EPA), we have reinvestigated the spurious sulfate formation. Clean filters of various kinds were exposed to extreme environmental conditions (100\% R.H. air at one atmosphere with 3 Torr partial pressure of $\mathrm{SO}_{2}$ ). As seen in Fig. 4, the sulfur saturated on these at a relatively low level, except for the case of the glass fiber filter. It is clear that the saturation level of spurious sulfur formation on Millipore filters is less than $0.5 \mu \mathrm{m} / \mathrm{cm}^{2}$. Similar extreme exposures of field samples from the RAPS network indicate that the sulfur increase due to $\mathrm{SO}_{2}$ conversion is limited to about $1.5 \%$ of the normal fine-particle load and $4 \%$ of the coarse-particle load.

An experiment was recently carried out to test the spurious sulfate formation under field conditions. Two samplers, $A$ and $B$, each equipped with a flow controller and an $152 \mathrm{~cm}$ inlet tube of $2.8 \mathrm{~cm}$ bore, were calibrated and used to sample side-by-side at $51 / \mathrm{m}$. One of the inlet tubes was coated with MgO to remove $\mathrm{SO}_{2}$ from the inlet airstream. The efficiency of one of these $\mathrm{SO}_{2}$ denuder tubes has been measured by EPA to be $99.5 \%$ at $50 \%$ relative humidity and at an inlet $\mathrm{SO}_{2}$ level of $400 \mathrm{ppb}$. The inlet tubes were alternated between the two samplers after each sampling period of 12 or 24 hours. Fresh denuder tubes were installed after one or two days of sampling to eliminate any possible saturation effects. The parallel samples, collected on 1 um pore size Teflon filters (Ghia Corporation, Pleasanton, California), were then compared by XRF analysis for sulfur and lead concentrations.

The results of this experiment are summarized in Table 3, while Fig. 5 shows the ambient $\mathrm{SO}_{2}$ level during the sampling period. By periodically interchanging the tubes and by normalizing the results in terms of the lead concentrations, any asymmetries between the samplers were eliminated. No detectable spurious sulfate formation was observed in these specimens. We, therefore, have no explanation for the reported $\mathrm{SO}_{2}$ conversion except that it may have occurred under a unique atmospheric condition. 


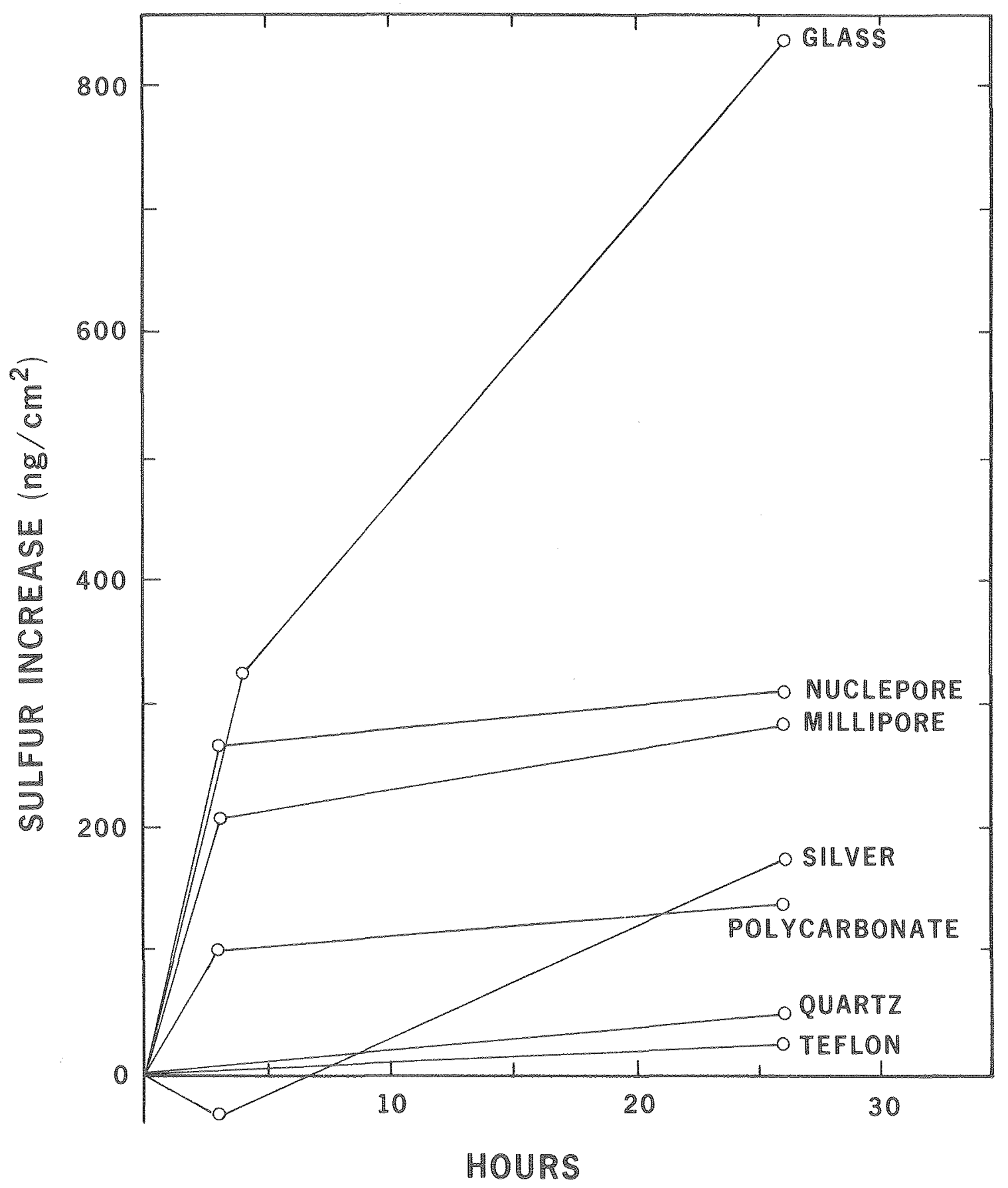

XBL 773-8022

Fig. 4 Spurious sulfate formation on clean filters under extreme exposures $\left(4,000 \mathrm{ppm} \mathrm{SO}_{2}\right.$ and $\left.100 \% \mathrm{R.H}.\right)$ 


\begin{tabular}{|c|c|c|c|c|c|c|c|c|c|c|}
\hline \multicolumn{2}{|c|}{$\begin{array}{l}\text { START } \\
\text { (MAY) }\end{array}$} & \multicolumn{2}{|c|}{ PERIOD } & \multicolumn{4}{|c|}{ TUBE WITH MgO COATING } & \multicolumn{3}{|c|}{ TUBE WITHOUT COATING } \\
\hline DAY & $H R$. & $H R$ 。 & MIN。 & SAMPLER & TUBE NO. & $\left(\mathrm{rg} / \mathrm{cm}^{2}\right)$ & $\begin{array}{c}\mathrm{pb} \\
\left(\mathrm{ng} / \mathrm{Cm}^{2}\right)\end{array}$ & SAMPLER & $\begin{array}{c}\mathrm{S} \\
\left(\mathrm{ng} / \mathrm{cm}^{2}\right)\end{array}$ & $\begin{array}{c}\mathrm{Pb} \\
\left(\mathrm{ng} / \mathrm{cm}^{2}\right) \\
\end{array}$ \\
\hline 12 & $9 \mathrm{am}$ & 10 & 52 & B & 1 & 1980 & 409 & A & 1931 & 392 \\
\hline 12 & $8 \mathrm{pm}$ & 11 & 57 & $\mathrm{~A}$ & 1 & 2412 & 630 & B & 2482 & 631 \\
\hline 13 & $8 \mathrm{am}$ & 11 & 39 & A & 2 & 3420 & 532 & $B$ & 3300 & 518 \\
\hline 13 & $8 \mathrm{pm}$ & 11 & 50 & $B$ & 2 & 4371 & 802 & $\mathrm{~A}$ & 4382 & 808 \\
\hline 14 & $8 \mathrm{am}$ & 11 & 44 & B & 3 & 3893 & 377 & A & 4012 & 384 \\
\hline 14 & $8 \mathrm{pm}$ & 12 & 03 & A & 3 & 4658 & 652 & $B$ & 4541 & 624 \\
\hline 15 & $8 \mathrm{am}$ & 11 & 33 & $\mathrm{~A}$ & 4 & 1830 & 122 & $B$ & 1782 & 119 \\
\hline 15 & 8 pm & 11 & 52 & B & 4 & 1164 & 437 & A & 1127 & 476 \\
\hline 16 & 8 am & 12 & 12 & $\mathrm{~A}$ & 4 & 2955 & 716 & $\mathrm{~B}$ & 2849 & 695 \\
\hline 16 & $8 \mathrm{pm}$ & 11 & 38 & $B$ & 4 & 2775 & 505 & A & 2778 & 508 \\
\hline 17 & $8 \mathrm{am}$ & 23 & 49 & B & 3 & 9058 & 1073 & $\mathrm{~A}$ & 9112 & 1111 \\
\hline 18 & $8 \mathrm{am}$ & 23 & 45 & A & 6 & 9437 & 924 & $B$ & 9173 & 877 \\
\hline
\end{tabular}

$\sum S / \sum P b$ (without Mgo) $\sum \mathrm{S} / \sum \mathrm{Pb}($ with $\mathrm{MgO})$ $=\frac{47469 / 7143}{47953 / 7179}$ $47953 / 7179$

0.995

$$
\frac{\sum P b(A)}{\sum P b(B)}=1.027
$$

Table 3 Resuits of spurious sulfate formation experiment in Charleston, West Virginia 


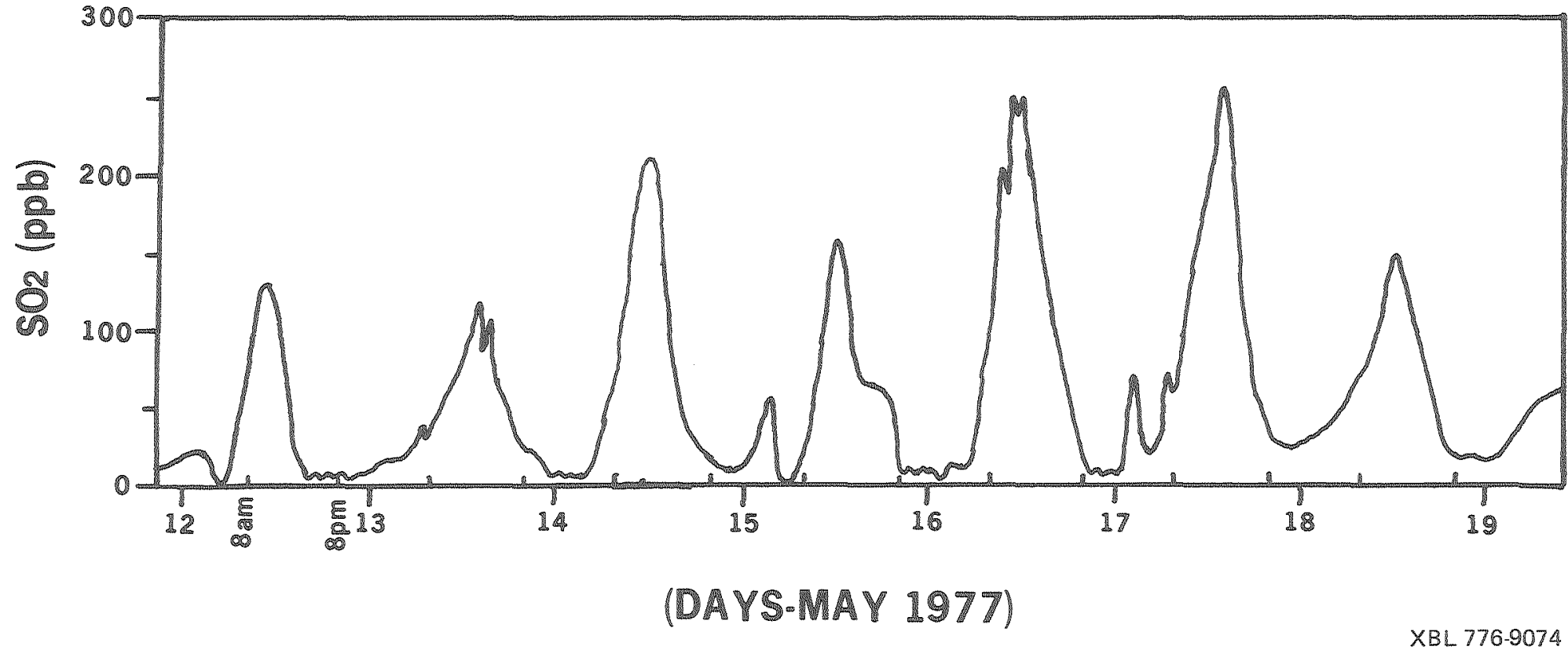

Fig. 5 Ambient $\mathrm{SO}_{2}$ variations during the investigation of possible sulfate formation in Charleston. West Virginia 


\section{RESULTS AND DISCUSSIONS}

We are now completing measurements on the RAPS aerosol samples and applying the recentiy-derived systematic corrections retroactively to data already in the EPA data bank. However, since substantial corrections, such as that for the sulfur migration effect, are required only for a small number of samples, we feel that some preliminary conclusions can be drawn from the present data.

Figure 6 is a map of the St. Louis area showing the location of the ten sampling sites (stations 103, 105, 106, 108, 112, 115, 118, 120, 122, and 124) that were equipped with automated dichotomous samplers. The metropolitan area is roughly encompassed by a $15 \mathrm{~km}$ radius circle centered about station 112. Brief descriptions of the local environment of each station are given in Table 4 . Included in Fig. 6 are the major fixed $\mathrm{SO}_{2}$ emission sources categorized according to their $\mathrm{SO}_{2}$ output in kilotons per year. (Lippman, 1977)

\section{(A) Temporal and Spatial Variations}

The short-term variations of fine-particle sulfur, lead, bromine, and zinc for two-hour samples collected at site 103 are contrasted in Fig. 7. Salient features of the results are:

(1) The time variations of sulfur are much slower than those of lead or bromine, which generally follow diurnal traffic patterns. Sulfur also exhibits little correlation with other elements.

(2) A constant lead-to-bromine ratio indicates automobile emission as the primary source of these elements. In general, our data corresponds to this situation but variations in the $\mathrm{Pb} / \mathrm{Br}$ ratio occur on occasion.

(3) The peaks due to non-automotive lead were well correlated with the zinc peaks on Julian (J) days 196 and 197. Trace elements such as zinc and copper characteristically show extreme short-term fluctuations which indicates highly varying source activities, short residence time in the air, or the proximity of the sampling site to a source (making it sensitive to wind direction). 


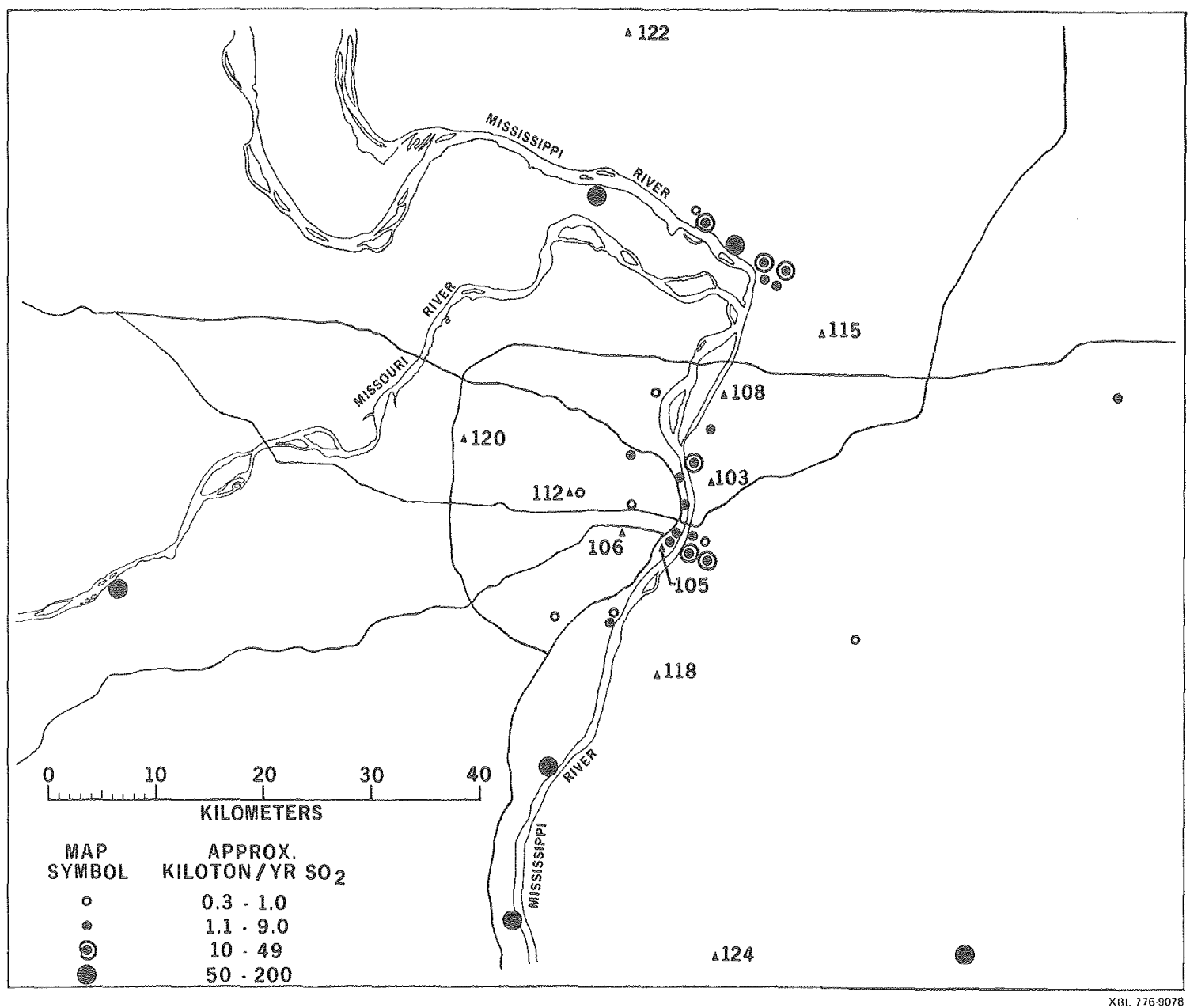

Fig. 6 RAPS sampling station locations (numbered) and major $\mathrm{SO}_{2}$ emission point sources. 


\begin{tabular}{|c|c|}
\hline STATTON & LOCAL ENVIRONMENT \\
\hline 103 & $\begin{array}{l}\text { National City, Tllinois. Amidst heavy indus- } \\
\text { tries, railroad, army depot and vehicular } \\
\text { traffic. Open area } 0.5 \mathrm{~km} \text { around site. Power } \\
\text { plant } 2.2 \mathrm{~km} \text { to the NW. }\end{array}$ \\
\hline 105 & $\begin{array}{l}\text { South central St. Louis. Among trucking and } \\
\text { warehousing operations. Close to chemical } \\
\text { plants. Heavy industry } 3 \mathrm{~km} \text { to the } \mathrm{E} \text {. }\end{array}$ \\
\hline 106 & $\begin{array}{l}\text { Within botanical garden. Central residential } \\
\text { district. Freeway } 0.1 \mathrm{~km} \text { to the } \mathrm{N} \text {. Steel } \\
\text { company } 0.8 \mathrm{~km} \text { to the } \mathrm{W} \text {. }\end{array}$ \\
\hline 108 & $\begin{array}{l}6 \mathrm{~km} \text { NW of Granite City, IIIinois, among farm- } \\
\text { land. Steel operations } 4.5 \mathrm{~km} \text { to the SE. } \\
\text { Cement plant } 5.8 \mathrm{~km} \text { to the } W \text {. }\end{array}$ \\
\hline 112 & $\begin{array}{l}\text { On athletic field of Washington University. } \\
\text { Highway } 2 \mathrm{~km} \text { to the } \mathrm{S} \text {. }\end{array}$ \\
\hline 115 & $\begin{array}{l}23 \mathrm{~km} \text { NE of St. Louis. Argicultural area. } \\
\text { Petrochemical plant } 5.8 \mathrm{~km} \text { to the NW. }\end{array}$ \\
\hline 118 & $\begin{array}{l}16 \mathrm{~km} \mathrm{~S} \text { of } 5 t \text {. Louis on farmland. Petrochem- } \\
\text { ical plants } 7 \mathrm{~km} \text { to the NE. }\end{array}$ \\
\hline 120 & $\begin{array}{l}24.5 \mathrm{~km} \text { W of St. Louis. Light industrial park. } \\
\text { Heavy traffic } 1.8 \mathrm{~km} \text { to } \mathrm{W} \text { and } 0.2 \mathrm{~km} \text { to the } \mathrm{S} \text {. }\end{array}$ \\
\hline 122 & $\begin{array}{l}45 \mathrm{~km} \text { of St. Louis. Agricultural area. No } \\
\text { major pollution source nearby. }\end{array}$ \\
\hline 124 & $\begin{array}{l}38.5 \mathrm{~km} \mathrm{~S} \text { of } \mathrm{St} \text { Louis. Agricultural area. } \\
\text { No major pollution source within several } \mathrm{km} \text {. }\end{array}$ \\
\hline
\end{tabular}

Table 4. Brief descriptions of the aerosol sampling locations in the RAPS network 

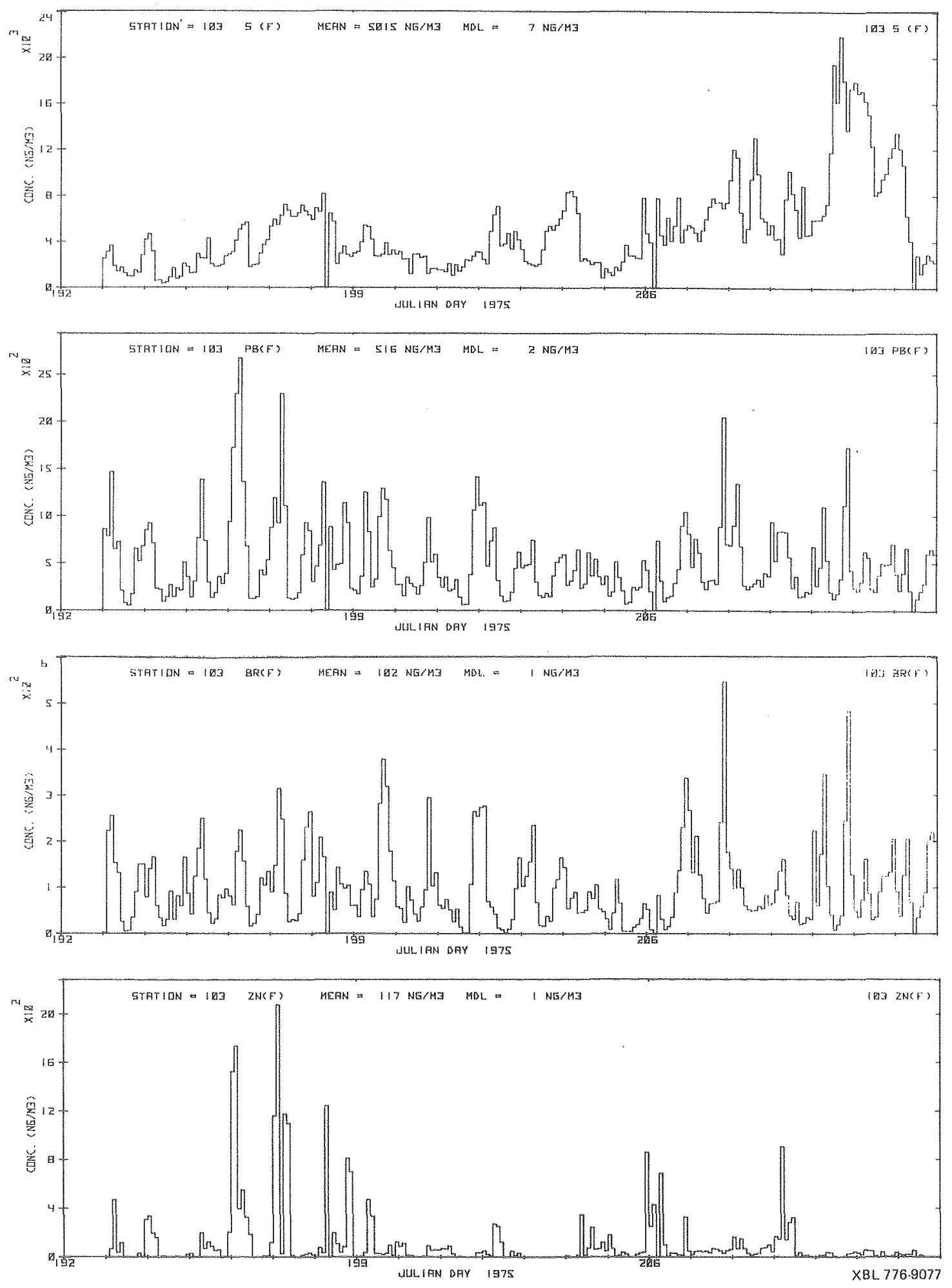

Fig. 7 Short-term temporal variations of fine particulate $\mathrm{S}, \mathrm{Pb}$, $\mathrm{Br}$, and $\mathrm{Zn}$ 
(4) During the sulfur episode on J days 210-212, which were plagued by ground fog and haze, zinc was nearly absent.

The intimate relationship between fine-particle sulfur and total particulate mass is illustrated in Fig. 8 where their temporal variations at station 120 are delineated in parallel; Fig. 9 is a scatter plot of the same data. The correlation coefficient between sulfur and mass was calculated to be 0.92 for these samples.

The spatial distributions of fine-particle sulfur and total aerosol mass are shown in Table 5, where the monthly averages for all ten stations during the latter half of 1975 are tabulated. The seasonal trends are apparent. Ratios of fine-particle sulfur to mass $S(F) / M(F)$ are seen to be fairly constant over all sampling stations, with the average ratio for the entire region being 0.117. Typically, the sulfate mass might be three times that of elemental sulfur: therefore, sulfates constitutes $\sim 35 \%$ of the fine aerosol mass. During a smog episode in 1975 ( $\mathrm{J}$ day 178-186), this rose to as much as $41 \%$. The relative constancy of the sulfur-to-mass ratio can be used as a useful quick cross-check between the two independent measurements ( $i$.e., sulfur determined by $x$-ray fluorescence and mass by beta-gauging).

(B) Wind Directional Spatial Variations

To better assess the impact of $\mathrm{SO}_{2}$ sources on local particulate sulfur levels, the sulfur data from the last four months of 1975 have been sorted into four groups according to the predominant wind directions: north, east, south, or west. (National Weather Service Office, 1975) The values are listed in Table 6.

For each of the four groups, the average fine-sulfur levels at various sites were compared with the level at an upwind reference stations and the ratios were calculated. Stations 108 and 118 were omitted in this comparison because they were sampled less frequently. Referring to Fig. 6, we see that stations 122,124 , and 120 , respectively, can be used as background stations when the winds are from the north, south, or west. Since there is no station located far upwind in the east, the remote station 122 was selected as a substitute background station. 

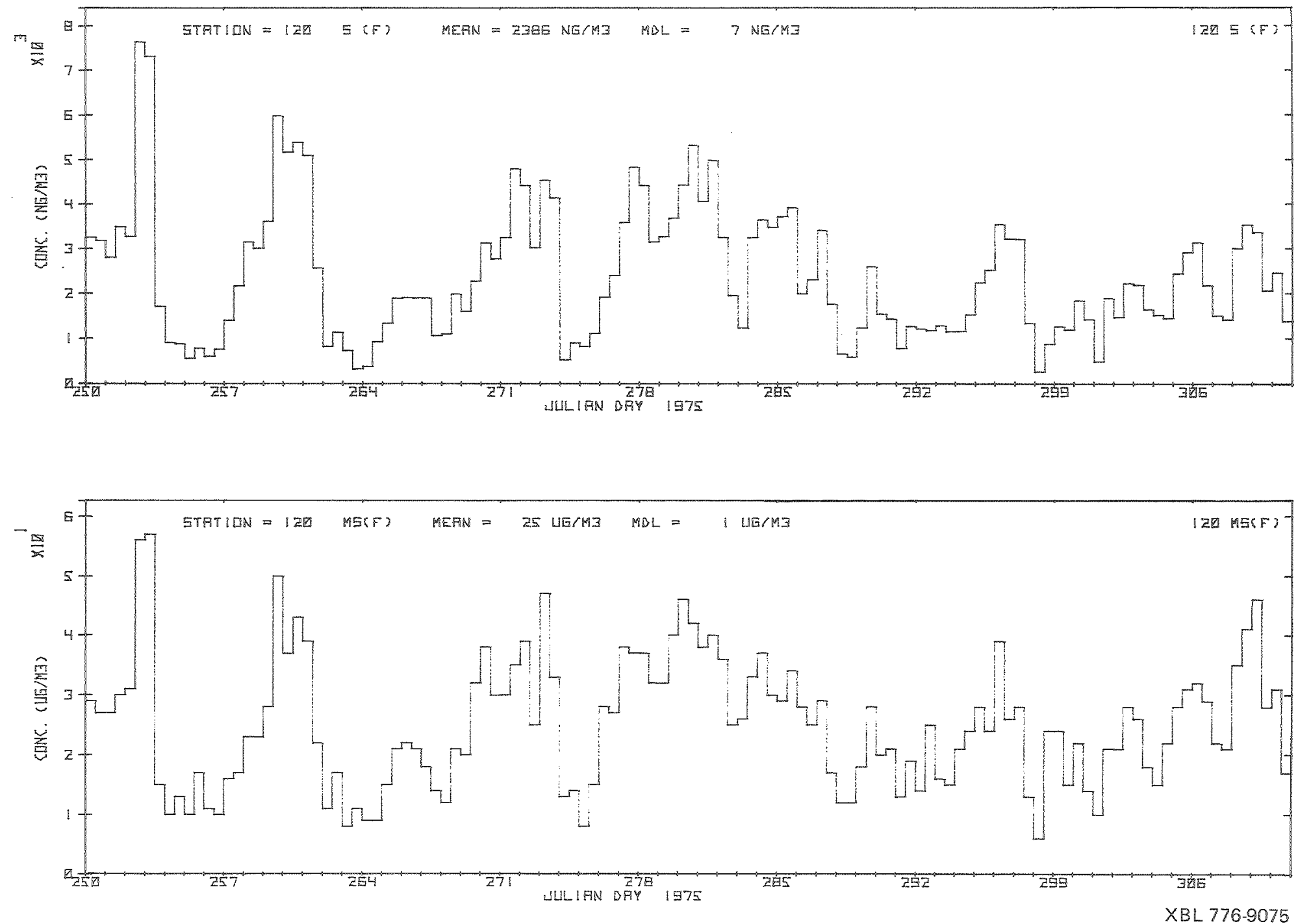

Fig. 8 Temporal variation of fine-particulate sulfur and mass 


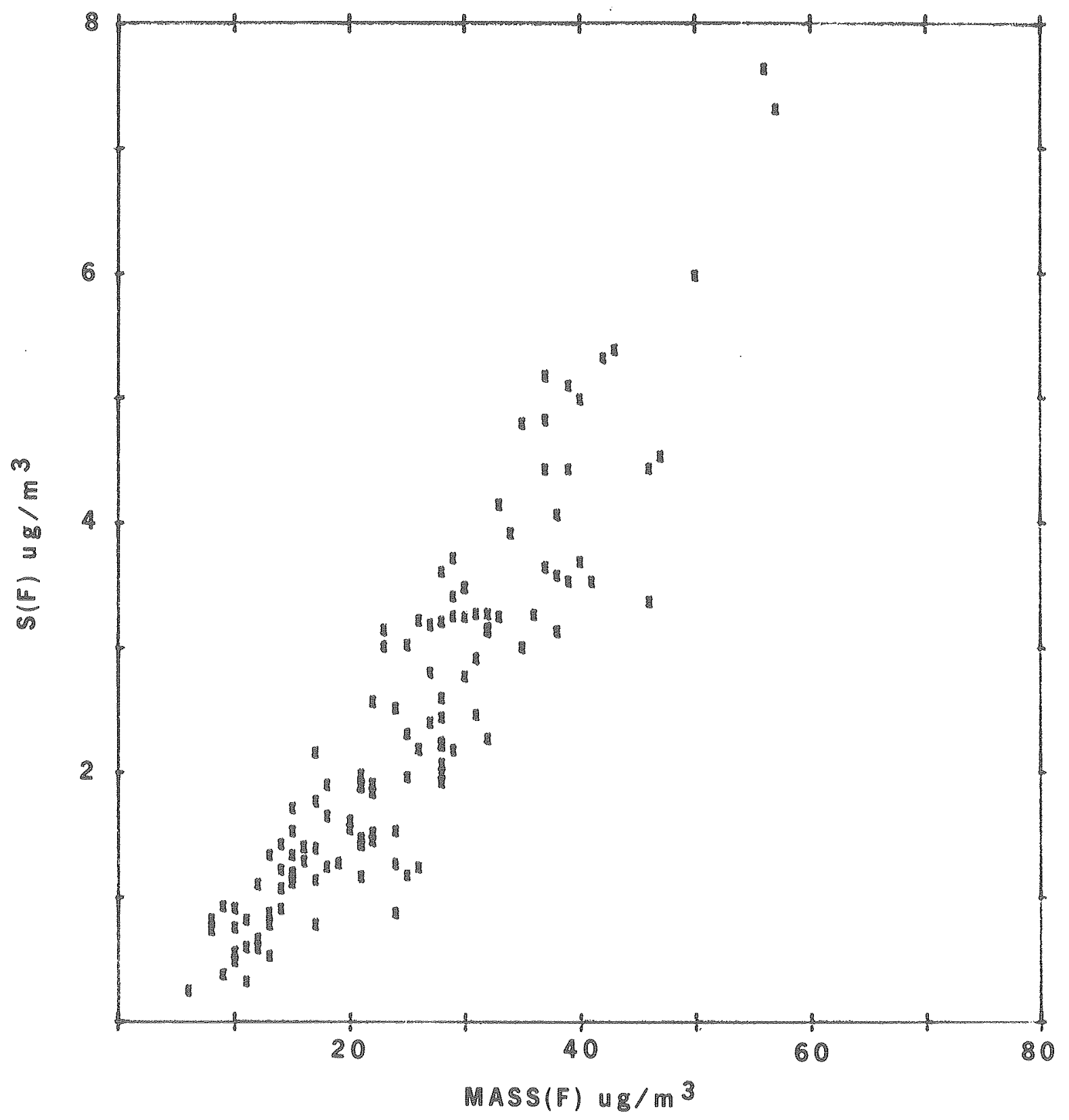

XBL 776.9080

Fig. 9 Correlation of fine-particulate sulfur and mass 
SULFUR (FINE) $\left(\mathrm{ng} / \mathrm{m}^{3}\right)$

\begin{tabular}{|l|c|c|c|c|c|c|c|c|c|c|}
\hline STATION & 103 & 105 & 106 & 108 & 112 & 115 & 118 & 120 & 122 & 124 \\
\hline JULY & 5663 & 5786 & 5427 & 4726 & 5277 & 5531 & 4940 & 4646 & 3954 & 3967 \\
\hline AUG. & 4900 & 4455 & 4142 & 3698 & 3719 & 3760 & 2818 & 3619 & 3607 & 3045 \\
\hline SEPT. & 3776 & 3793 & 3158 & 2761 & 3037 & 2626 & 2627 & 2684 & 2181 & 2916 \\
\hline OCT. & 2986 & 2818 & 2705 & 2196 & 2584 & 2301 & 2100 & 2205 & 1721 & 1972 \\
\hline NOV. & 2352 & 2228 & 2128 & 2093 & 2055 & 1911 & 1496 & 1789 & 1843 & 1470 \\
\hline DEC. & 2818 & 2748 & 2589 & 2576 & 2716 & 2492 & 1961 & 2397 & 2196 & 1584 \\
\hline $\begin{array}{l}\text { SIX MO. } \\
\text { AVERAGE }\end{array}$ & 3733 & 3638 & 3358 & 3008 & 3231 & 3104 & 2657 & 2890 & 2584 & 2492 \\
\hline
\end{tabular}

MASS (FINE) $\left(\mu \mathrm{g} / \mathrm{m}^{3}\right)$

\begin{tabular}{|l||c|c|c|c|c|c|c|c|c|c|}
\hline STATION & 103 & 105 & 106 & 108 & 112 & 115 & 118 & 120 & 122 & 124 \\
\hline \hline JULY & 55.6 & 50.0 & 48.6 & 36.3 & 50.0 & 42.3 & 34.5 & 36.2 & 33.0 & 27.4 \\
\hline AUG. & 46.8 & 31.2 & 29.4 & 28.1 & 29.4 & 25.6 & 18.3 & 21.2 & 27.1 & 18.7 \\
\hline SEPT. & 31.7 & 28.9 & 27.2 & 23.7 & 22.4 & 19.5 & 17.7 & 25.6 & 20.3 & 20.6 \\
\hline OCT. & 43.4 & 37.2 & 25.7 & 25.5 & 24.2 & 20.0 & 15.1 & 24.5 & 23.2 & 16.5 \\
\hline NOV. & 20.8 & 27.0 & 20.1 & 25.3 & 22.1 & 17.3 & 12.8 & 23.6 & 16.9 & 17.3 \\
\hline DEC. & 24.1 & 26.6 & 20.6 & 23.2 & 21.3 & 19.7 & 15.6 & 21.5 & 17.5 & 13.5 \\
\hline \hline $\begin{array}{l}\text { SIX MO. } \\
\text { AVERAGE }\end{array}$ & 37.1 & 33.5 & 28.6 & 27.0 & 28.2 & 24.1 & 19.1 & 25.4 & 23.0 & 19.0 \\
\hline S(F)/M(F) & 0.10 & 0.11 & 0.12 & 0.11 & 0.11 & 0.13 & 0.14 & 0.11 & 0.11 & 0.13 \\
\hline
\end{tabular}

Table 5 Long-term temporal and spatial distributions of fine-particulate sulfur and mass (1975) 
SULFUR (FINE)

\begin{tabular}{|c|c|c|c|c|c|c|c|c|}
\hline \multirow{2}{*}{ STATION } & \multicolumn{2}{|c|}{ NORTH } & \multicolumn{2}{c|}{ EAST } & \multicolumn{2}{c|}{ SOUTH } & \multicolumn{2}{c|}{ WEST } \\
\cline { 2 - 8 } & $\mathrm{ng} / \mathrm{m}^{3}$ & ratio & $\mathrm{ng} / \mathrm{m}^{3}$ & ratio & $\mathrm{ng} / \mathrm{m}^{3}$ & ratio & $\mathrm{ng} / \mathrm{m}^{3}$ & ratio \\
\hline 103 & 2819 & 1.70 & 3466 & 1.50 & 2622 & 1.29 & 3251 & 2.21 \\
105 & 2949 & 1.78 & 3149 & 1.36 & 2450 & 1.20 & 2636 & 1.80 \\
1126 & 3440 & 2.08 & 2266 & 0.98 & 2464 & 1.21 & 2556 & 1.74 \\
115 & 2396 & 1.45 & 2614 & 1.13 & 2233 & 1.10 & 2298 & 1.57 \\
120 & 1841 & 1.11 & 3625 & 1.56 & 2349 & 1.15 & 1468 & 1.00 \\
122 & 1657 & 1.00 & 2317 & 1.00 & 2129 & 1.05 & 2044 & 1.39 \\
124 & 1862 & 1.12 & 2719 & 1.17 & 2037 & 1.00 & 1735 & 1.18 \\
\hline
\end{tabular}


The fact that minor $\mathrm{SO}_{2}$ sources are not included in the analysis and that wind directions are divided only roughly into four quadrants makes the interpretation of the results in Table 6 rather general. However, the following features seem to emerge:

(1) The downwind stations always exhibit higher sulfur levels than the background stations showing that the city contributes a significant burden to the atmosphere.

(2) As a whole, the background air masses arriving from west and north of St. Louis have about 30\% Tower particulate sulfur than those from the east and south. This result probably reflects the long-distance transport of sulfur from sources in the industrial east coast areas of the United States.

(3) Considering the orientation of the sampling stations with respect to the major emission sources, we find the relative amount of sulfur increase to be consistent with the observed wind directions. For example, station 120 had the lowest sulfur level of all stations when the wind was from the west, the largest increase $156 \%$ when the wind was from the east, and moderate increases of $11 \%$ and $15 \%$ when the winds were from the north and south, respectively. These crosswind comparisons are only qualitative because of the uncertainties in comparing data sets taken for different time periods and under different conditions.

(4) The remote stations show a smaller sulfur increase than the urban stations, even though the remote stations are downwind from the city. For instance, station 124 shows only a $12 \%$ sulfur increase when the wind is from the north and station 122 shows only a $5 \%$ increase when the wind is from the south, while the urban stations experience increases of more than $50 \%$ in both cases. This suggests that the effect of the emission sources (in terms of particulate sulfate) is either short-ranged 
or highly directional. To address this question, we examined some shortaterm sulfur distributions, where the effect on a distant station is less diluted by changes in wind direction that occurs in long-term averages. Table 7 shows examples of sulfur distributions averaged over six-hour periods during which wind direction and speed were known to be quite steady. The distant downwind stations now have sulfur increases comparable to those of the city stations. We therefore conclude that the emission sources have long-range (at least $40 \mathrm{~km}$ ) and rather directional impact on their downwind environment. Note that the air mass from the north was quite clean on J day 218 (1975): thus, even though the sulfur levels downwind were not excessive on that date, the percentage increase was exceptionally high.

(C) Aerosol Composition

Table 8 shows results for a number of elements for four representative stations throughout the region. Both size fractions are represented. The results given are mean concentrations over about one-month period in June/July 1975. Although the aerosol mass is almost evenly divided between the two size-fractions, nearly $90 \%$ of the sulfur is found in the fine fraction. Iron (generally a soil component) is found largely in the coarse-particle fraction. For other elements, the actual concentrations show wide spatial variations, although the percentage in each of the size-fractions is quite constant.

It is of interest to note that lead to bromine ratio in the fineparticle fraction, an indicator of the age of the automobile emission aerosol (Robbins, 1972), is significantly higher at the rural sites than at the urban stations. However, the actual $\mathrm{Pb} / \mathrm{Br}$ ratios shown in Table 6 are not typical. Long-term data (4 month averages) reveal that the range of such ratios between urban and rural sites are from $3 \cdot 1$ to $6 \cdot 1$. 
SULFUR (FINE)

\begin{tabular}{|c|c|c|c|c|c|c|c|c|}
\hline JULIAN DAY (1975) & \multicolumn{2}{|c|}{218.25} & \multicolumn{2}{|c|}{211.25} & \multicolumn{2}{|c|}{222.0} & \multicolumn{2}{|c|}{208.25} \\
\hline WIND DIRECTION & \multicolumn{2}{|c|}{$15^{\circ}$} & \multicolumn{2}{|c|}{$85^{\circ}$} & \multicolumn{2}{|c|}{$190^{\circ}$} & \multicolumn{2}{|c|}{$255^{\circ}$} \\
\hline WIND SPEED (KNOT) & \multicolumn{2}{|c|}{8.5} & \multicolumn{2}{|c|}{3.5} & \multicolumn{2}{|c|}{7.0} & \multicolumn{2}{|c|}{6.0} \\
\hline RELATIVE HUMIDITY (\%) & \multicolumn{2}{|c|}{98} & \multicolumn{2}{|c|}{87} & \multicolumn{2}{|c|}{90} & \multicolumn{2}{|c|}{88} \\
\hline STATION & $\mathrm{ng} / \mathrm{m}^{3}$ & ratio & $\mathrm{ng} / \mathrm{m}^{3}$ & ratio & $\mathrm{ng} / \mathrm{m}^{3}$ & ratio & $\mathrm{ng} / \mathrm{m}^{3}$ & ratio \\
\hline 103 & 4706 & 5.91 & 14605 & 1.55 & 7123 & 1.52 & 5245 & 1.17 \\
\hline 105 & 5399 & 6.78 & 13306 & 1.41 & 5859 & 1.25 & 4735 & 1.06 \\
\hline 106 & 4398 & 5.53 & 11184 & 1.19 & 5663 & 1.20 & 4311 & 0.96 \\
\hline 112 & 3102 & 3.90 & 14011 & 1.48 & 6478 & 1.38 & 4319 & 0.96 \\
\hline 115 & 2302 & 2.89 & 10201 & 1.08 & 5207 & 1.11 & 5642 & I. 26 \\
\hline 120 & 3410 & 4.28 & 10093 & 1.07 & 6624 & 1.41 & 4.481 & 1.00 \\
\hline 122 & 796 & 1.00 & 9437 & 1.00 & 5919 & 1.26 & 4452 & 0.99 \\
\hline 124 & 3774 & 4.74 & 8226 & .87 & 4700 & 1.00 & 4252 & 0.95 \\
\hline
\end{tabular}

Table 7 Short-term ( 6 hour average) wind directional sulfur distribution 


\begin{tabular}{|c|c|c|c|c|}
\hline STATION & 103 & 112 & 118 & 122 \\
\hline Mass (C) $\mu \mathrm{g} / \mathrm{m}^{3}$ & 38 & 34 & 25 & 22 \\
Mass (F) & $51(57 \%)$ & $35(51 \%)$ & $30(55 \%)$ & $27(55 \%)$ \\
\hline $\mathrm{S}(\mathrm{C}) \mu \mathrm{g} / \mathrm{m}^{3}$ & 701 & 816 & 579 & 354 \\
$\mathrm{~S}(\mathrm{~F}) \mu \mathrm{g} / \mathrm{m}^{3}$ & $5620(89 \%)$ & $3933(83 \%)$ & $3736(87 \%)$ & $3387(91 \%)$ \\
$\mathrm{Fe}(\mathrm{C}) \mu \mathrm{g} / \mathrm{m}^{3}$ & $1421(88 \%)$ & $1261(88 \%)$ & $671(87 \%)$ & $528(87 \%)$ \\
$\mathrm{Fe}(\mathrm{F}) \mu \mathrm{g} / \mathrm{m}^{3}$ & 200 & 180 & 98 & 80 \\
$\mathrm{Zn}(\mathrm{C}) \mu \mathrm{g} / \mathrm{m}^{3}$ & 73 & 40 & 12 & 15 \\
$\mathrm{Zn}(\mathrm{F}) \mu \mathrm{g} / \mathrm{m}^{3}$ & $133(65 \%)$ & $64(62 \%)$ & $30(71 \%)$ & $45(75 \%)$ \\
$\mathrm{Pb}(\mathrm{C}) \mu \mathrm{g} / \mathrm{m}^{3}$ & 128 & 192 & 60 & 23 \\
$\mathrm{~Pb}(\mathrm{~F}) \mu \mathrm{g} / \mathrm{m}^{3}$ & $573(82 \%)$ & $705(79 \%)$ & $213(78 \%)$ & $153(87 \%)$ \\
$\mathrm{Br}(\mathrm{C}) \mu \mathrm{g} / \mathrm{m}^{3}$ & 24 & 52 & 8 & 3 \\
$\mathrm{Br}(\mathrm{F}) \mu \mathrm{g} / \mathrm{m}^{3}$ & $108(82 \%)$ & $133(72 \%)$ & $26(76 \%)$ & $16(84 \%)$ \\
\hline $\mathrm{Pb}(\mathrm{F}) / \mathrm{Br}(\mathrm{F})$ & 5.3 & 5.3 & 8.2 & 9.6 \\
\hline
\end{tabular}

Table 8 Aerosol compositions over four representative stations 
CONCLUSION

The sampling and analysis system used in this study represents an integral approach to large-scale aerosol monitoring, including particle sizing, mass analysis, and elemental concentration measurements. We feel that the inherent advantages of the XRF technique have been ful1 demonstrated in the study and that the analytical corrections required for sulfur analysis are sufficiently well defined to make the technique accurate and reproducible.

In the course of this study, we have advanced from utilizing a large computer center for complex data sorting to using a dedicated data system with a large (40M word) disc. More complete analysis of the experimental data obtained in large-scale studies will require the systematic treatment of very large data sets including visibility, meteorolow gical, and gaseous data. The disc-based system will vastly improve the capacity to handle large volumes of data and of our ability to examine the correlation patterns. 


\section{ACKNOWLEDGMENTS}

A large-scale study of this nature of necessity involves many contributors. We thank all our collaborators at the Lawrence Berkeley Laboratory including R. Adachi, R. Fisher, R. Giauque, B. Jarrett, D. Landis, N. Madden, J. Meng, A. Ramponi, and W. Searles. We also appreciate the work of the staff of the Rockwell International Science Center in St. Louis and particularly that of D. Hern, A. Jones, L. Myers, and E. Nelson. 


\section{REFERENCES}

Appe1, B. R., E. L. Kothny, E. M. Hiffer, G. C. Buell, S. M. Wall, and J. J. Wesolowski, (1977) "A Comparative Study of Wet Chemical and Instrument Methods for Sulfate Determination." Symposium Preprint, Division of Environmental Chemistry, ACS, 173rd National Meeting, New Orleans, Louisiana, March 20-27. pp. 117-120. Camp, D. C., A. L. VanLehn, J.R. Rhodes, and A. H. Pradzynski, (1975) "Intercomparison of Trace Element Determinations in Simulated and Real Air Particulate Samples." X-ray Spectrometry, V. 4, pp. 123-137.

Dzubay, T. G. and P. J. Lamothe, (1977) "Polymer Film as Calibration Standards for X-ray Fluorescence Analysis." Advances in X-ray Analysis, V. 20, pp. 411-421.

Giauque, R. D., R. B, Garrett, and L. Y. Goda, (1977) "Calibration of Energy-Dispersive X-ray Spectrometers for Analys is of Thin Environmental Samples." In X-ray Fluorescence Analysis of Environmental Samples, T. G. Dzubay, Ed. An Arbor Science, pp. 153-164. Goulding, F. S., J. M. Jaklevic, and B. W. Loo, (1975) "Fabrication of Aerosol Monitoring System for Determining Mass and Composition as a Function of Time." Environmental Protection Agency Report No. EPA-650/2-75-048, EPA Research Triangle Park, North Carolina. Jaklevic, J. M., B. W. Loo, and F. S. Goulding, (1977) "PhotonInduced $X$-ray Fluorescence Analysis Using Energy-Dispersive Detector and Dichotomous Sampler." In X-ray Fluorescence Analysis of Environmental Samples, T. G. Dzubay, Ed. Ann Arbor Science, pp. 3-18.

Jaklevic, J. M. and R. L. Walter (1977A) "Comparison of Minimum Detectable Limits Among X-ray Spectrometers." In X-ray Fluorescence Analys is of Environmental Samples, T. G. Dzubay, Ed. Ann Arbor Science, $p p .63-75$. 
Lasko, L. J., M. C. Washeleski, K. E. Noll, and H. E. Allen, (1977) "Continuous Sulfate Monitoring Program in a Large Urban Area," Symposium Preprint, Division of Environmental Chemistry, ACS, 173rd National Meeting, New Orleans, Louisiana, March 20-27, pp. 175-176. Lippman. F. (1977). Major $\mathrm{SO}_{2}$ sources information provided by Mr. Lippman, Rockwell International Science Center from the point source emission inventory of the St. Louis Regional Air Pollution study.

Liu, B.Y.H. and G. A. Kuhtmey, (1977) "Efficiency of Air Sampling Filter Media." In X-ray Fluorescence Analys is of Environmental Samples, T. G. Dzubay, Ed. An Arbor Science, pp. 107-119. Loo, B. W. J. M. Jaklevic, and F. S. Goulding, (1976) "Dichotomous Virtual Impactors for Large-Scale Monitoring of Airborne Particulate Matter." In Fine Particles: Aerosol Generation, Measurement, Sampling and Analysis, B.Y,H. Liu, Ed. Academic Press, New York. pp. 311-350.

Loo, B. W., R. C. Gatti, B.Y.H. Liu, C. S. Kim, and T. G. Dzubay, (1977) "Absorption Corrections for Submicron Sulfur Collected in Filters." In X-ray Fluorescence Analysis of Environmental Samples, T. G. Dzubay, Ed. Ann Arbor Science, pp. 187-202. NWSO (1975). Wind data taken from Local Climatological Data, National Weather Service Office, St. Louis International Airport. Pierson, W. R., (1977) "Spurious Sulfate in Aerosol Sampling: A Review." Symposium Preprint, Division of Environmental Chemistry, ACS, 173rd National Meeting, New Orleans, Louisiana, March 20-27. pp. $165-167$.

Robbins, J. A. and F. L. Snitz, (1972) "Bromide and Chlorine Loss from Lead Halide Automobile Exhaust Particulates." Environmental Science and Technology, V. 6, No. 2, February. pp. 164-169. 
Stevens, R. K., T. G. Dzubay, G. Russwurm, and D. Rickle, (1978) "Sampling and Analysis of Atmospheric Sulfate and Related Species." Proceedings of International Symposium on Sulfur in the Atmosphere, Sept. 7-14, 1977, Dubrovnik, Yugoslavia. To be published in Atmospheric Environment, V. 12, No. 1.

Whitby, K. T., R. B. Husar, and B.Y.H. Liu, (1972) "The Aerosol Size Distribution of Los Angeles Smog." In Aerosols and Atmospheric Chemistry, Hidy, G. M. (ed.). Academic Press, pp. 137-264.

Whitby, K. T., (1973) On the Multimodal Nature of Atmospheric Aerosol Size Distribution. Particle Technology Lab Publication No. 218. University of Minnesota. 
This report was done with support from the United States Energy Research and Development Administration. Any conclusions or opinions expressed in this report represent solely those of the author(s) and not necessarily those of The Regents of the University of California, the Lawrence Berkeley Laboratory or the United States Energy Research and Development Administration. 